\title{
AS DIFICULDADES DE ATENAS PARA O RETORNO À DEMOCRACIA DEPOIS DO GOLPE DOS QUATROCENTOS
}

Profa. Dra. Lorena Lopes da Costa ${ }^{1}$

\begin{abstract}
Resumo: O presente artigo tem como objeto a peça Filoctetes de Sófocles, integrante da trilogia que vence as Grandes Dionísias em 409 a. C, ano em que se dá o primeiro festival depois da retomada do poder pelo povo após o Golpe dos Quatrocentos. Na peça de Sófocles, Filoctetes continua a ser o herói solitário. Ele é, porém, ao mesmo tempo, o herói que deve ser reintegrado à pólis. Ao lado dele, Neoptólemo, personagem que modifica consideravelmente o mito em Sófocles, transforma-se, à medida que a história se desenvolve, no novo guerreiro aqueu, o qual aprende a reconhecer o valor da philía e o valor da unidade, mas que não o faz sem convidar os atenienses espectadores a refletirem sobre os juramentos cívicos e sobre a unidade que tais ritos buscavam consumar.
\end{abstract}

Palavras-chaveः Filoctetes; Herói; Pólis; Democracia.

\section{I - Filoctetes de Sófocles e a vitória nas Grandes Dionísias de 409 A. C.}

Filoctetes de Sófocles pergunta à pólis: o herói do passado pode coexistir com a cidade, consciente de que é um herói do passado (VIDAL-NAQUET, 2009)?² Depois do Golpe Oligárquico dos Quatrocentos, de 411 a. C. (pelo qual vota o poeta), e do restabelecimento da democracia, com a deteriorada imagem da guerra, a peça de Sófocles renova o mito clamando pela unidade. Encenada e vitoriosa nas Grandes Dionísias de 409 a. C., Filoctetes apresenta respostas novas aos dilemas da cidade e às novidades da guerra que se vivia.

Filoctetes é o herói solitário no século de Péricles, no século em que a coletividade busca se firmar e se afirmar enquanto princípio. Ele é, porém,

\footnotetext{
1 Doutora em História, pela UFMG, sob orientação do Prof. Dr. José Antonio Dabdab Trabulsi. Pós-doutoranda na UFOP. E-mail para contato: lorenalopes85@gmail.com

2 Quem faz a pergunta é Pierre Vidal-Naquet, embora o autor se pergunte a respeito de Ájax, um herói que, de forma análoga a Filoctetes, mas com um fim diferente, vai enfrentar a mesma dificuldade.
} 
ao mesmo tempo, o herói que deve ser reintegrado vivo à pólis. Ao lado dele, Neoptólemo, personagem que modifica consideravelmente o mito em Sófocles, transforma-se, à medida que a história se desenvolve, no novo guerreiro aqueu, o qual aprende a reconhecer o valor da philía e o valor da unidade, mas que não o faz sem convidar os atenienses espectadores a refletirem sobre os juramentos cívicos e sobre a unidade que tais ritos buscavam consumar.

Com efeito, dois anos antes da apresentação de 409 a. C., o poder ateniense havia se transformado num "monstro bicéfalo" (JOUANNA, 2007, p. 61), ${ }^{3}$ do qual uma cabeça estava em Atenas, pois os Quatrocentos haviam dissolvido a Assembleia e se esforçavam por anular as instituições democráticas, e a outra em Samos, onde os estrategos democratas faziam a guerra a favor da democracia. Tucídides conta-nos que, após terem se reunido na Assembleia em Colono (e não na Pnyx como era o uso democrático), os Quatrocentos se estabelecem na sala do antigo Conselho e enfrentam, a partir de então, a resistência dos hoplitas organizados no Pireu, além da ameaça das forças que se rebelam em Samos.

Conforme o cenário descrito pelo historiador (TUCÍDIDES, VIII, 93), os hoplitas exercem importante papel: por um lado, eles resistem no Pireu, ainda que apresentem um caráter mais conciliatório do que os hoplitas e marinheiros que, noutra parte, precisamente acampados em Samos, resistem de maneira mais exacerbada às mudanças orquestradas pelos Quatrocentos. As duas frentes demonstram a atitude política dos guerreiros, além da conexão profunda do dêmos com o regime democrático, embora se saiba que o fim do regime oligárquico dos Quatrocentos se dê mais por meio de uma harmonização entre as forças, diante da ameaça lacedemônica sobre Salamina, do que pela vitória da democracia (TUCÍDIDES, História da Guerra do Peloponeso, VIII, 68, 4). ${ }^{4}$

As Grandes Dionísias de 409 a. C., que Sófocles vence, são assim não apenas o primeiro festival depois da retomada do poder pelo povo, mas um festival em que esse poder é imensamente afirmado, seja por meio da repetição de ritos já conhecidos do festival (retomando a ligação da cidade com seu

3 São de minha autoria trechos de autores antigos e da bibliografia secundária, quando não houver tradutor mencionado nas referências. Ademais, sempre que for assim, o texto original será citado em nota de pé de página. Texto original: La puissance athénienne était devenue un monstre bicéphale, chaque tête (Samos et Athènes) prenant ses propres décisions (JOUANNA, 2007, p. 61).

4 A fim de conter o avanço lacedemônico em Salamina, os Quatrocentos decidem enviar uma frota ateniense, que, não obstante, sofre uma derrota desastrosa. A derrota propicia a derrocada dos oligarcas atenienses, já que, após o desastre, os atenienses decidem-se reunirem na Pnyx, lugar em que haviam deixado de se reunir depois do golpe, para darem fim o regime golpista. 
passado democrático), seja por meio da instituição de novos ritos (reforçando essa ligação): um deles consiste exatamente no Juramento de Demofanto, segundo o qual todo cidadão ateniense se compromete a matar possíveis tiranos

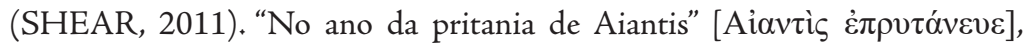
donde se conclui tratar-se do ano de 410-9, a Boulé institui o decreto que, contém, por sua vez, este novo juramento a ser prestado pelos cidadãos:

\begin{abstract}
"Matarei, por palavra, por feito, por voto, por minha própria mão, se eu puder, qualquer um que derrube a democracia em Atenas, e qualquer um que, tendo a democracia sido derrubada, ocupe algum cargo. Matarei qualquer um que se estabeleça para ser o tirano ou que ajude qualquer um a se estabelecer. Julgarei piedoso, à luz dos deuses e dos espíritos, qualquer um que o matar, por matar um inimigo dos atenienses. Venderei todos os bens do morto e dou uma metade ao assassino, sem deixar nada para trás. E se alguém morrer ao matar ou ao tentar matar esse tipo de homem, tomarei conta dele e de seus filhos, assim como de Harmódio e Aristogíton e seus descendentes. Todos os juramentos jurados contra o povo de Atenas, em Atenas, em campanha, ou onde quer que tenha sido, declaro nulos e sem efeito" (ANDÓCIDES, Mistérios, I, 96) 5
\end{abstract}

Segundo o juramento citado por Andócides, o mau cidadão passa a ser um inimigo da cidade. $\mathrm{O}$ texto declara que qualquer um que derrube a democracia ou assuma um cargo fora do regime democrático torna-se inimigo [ $\pi \mathrm{o} \lambda \varepsilon ́ \mu 10 \varsigma]$ público dos atenienses, devendo por isso ser morto, ao passo que o bom cidadão, seu assassino (bem como os cúmplices do assassinato, caso

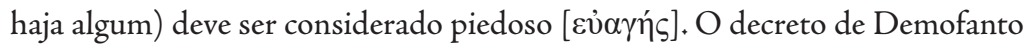
é um dos elementos que permite apreender o teor do processo de retomada e afirmação do passado democrático decorrente da deposição dos Quatrocentos. A preocupação do decreto com a democracia é explícita: qualquer ameaça deve ser extirpada de forma extrema. Mas a nova lei é apenas uma parte de um grupo heterogêneo de leis, que buscam a proteção máxima do regime do povo. Trata-se de fazer cada cidadão sentir-se parte ativa e responsável pela democracia, dando a ela o aspecto de uma unidade, que teria sido quebrada

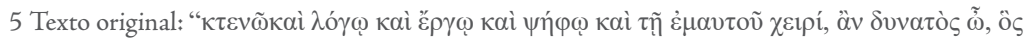

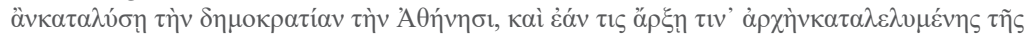

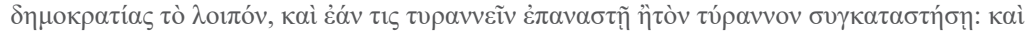

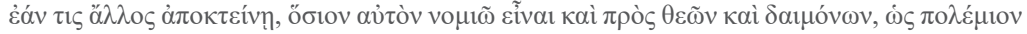

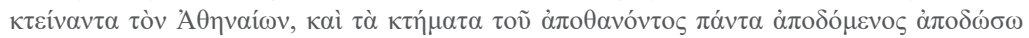

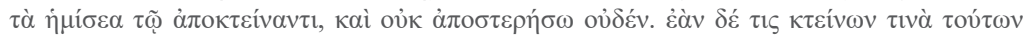

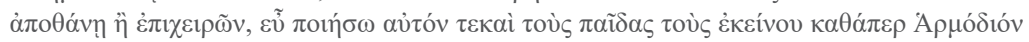

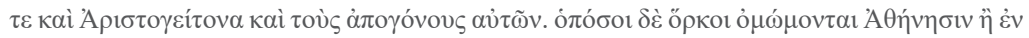

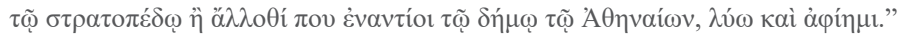


pelos Quatrocentos, mas que jamais deveria voltar a ser. Para tanto, Atenas, em primeiro lugar, promove um claro resgate do passado democrático, em segundo, elimina as marcas do recente golpe oligárquico, que não é mencionado nos novos documentos e tem suas estelas removidas da Ágora, em terceiro, cria novos ritos que, como o Jurameno de Demofanto, filiam a democracia do presente ao passado democrático. ${ }^{6}$ Coletivamente, as novas e as velhas inscriçóes, os novos e os velhos ritos trabalham para redefinir e reformar o espaço público, funcionando como memoriais, celebrando a democracia e servindo ainda como manuais de ação contra qualquer força contrária ao regime (SHEAR, 2011). Dessa forma, o Juramento de Demofanto é apenas um dos elementos utilizados pela pólis para fortalecer esse sentimento de unidade em torno da democracia, uma unidade que se faz ver durante as Grandes Dionísias. Os ritos do festival - o voto de Demofanto, as libações dos generais, a apresentação do tributo, dos órfãos de guerra e o anúncio dos ganhadores da coroa de ouro - buscam, enfim, confirmar de forma repetitiva o poder da democracia, unindo todos os cidadãos em torno dela, a fim de que, assentados lado a lado, formem um só corpo, partilhem os mesmos ritos e homenageiem os mesmos deuses.

Não obstante, esse esforço político será diretamente questionado por uma das peças que integram a trilogia vencedora do ano de 409 a. C., uma vez que Filoctetes de Sófocles sugere as dificuldades a serem enfrentadas para que a oligarquia seja sobrepujada. Ao contrário do que fazem pensar os juramentos e os outros ritos, esse combate não há de ser nada fácil. A peça de Sófocles coloca em cena exatamente as dificuldades que existem na criação da unidade, elemento tão necessário à defesa da democracia.

\section{II - Filoctetes, o herói de outrora, e Odisseu, o herói da PóLIS?}

Filoctetes não é apenas o mais solitário dos heróis de Sófocles, o homem que viveu dez anos abandonado numa ilha deserta acometido pela grave ferida. Ele é ainda o mais injustiçado de todos (KNOX, 1974): seu abandono pelos companheiros de guerra não se deveu à desonra, à traição ou a qualquer outra justificativa legítima, mas à repugnância que os companheiros sentiam do

\footnotetext{
6 A pólis assiste, pouco tempo depois do golpe dos Quatrocentos, a um intenso exercício de reprodução de leis já conhecidas (como a lei de Drácon, que segundo Andócides, inspira o decreto de Demofanto), as quais, inscritas em estelas sobretudo no Bouleutérion e na Ágora, tornam concretamente visíveis os signos da história da democracia enquanto unidade. Drácon, Sólon, Clístenes, ao lado dos novos democratas, unem-se numa imagem só, que exclui e não tolera interferências oligárquicas nem tirânicas, como as do passado recente.
} 
cheiro que a ferida exalava e à inabilidade que demonstravam para lidar com sua dor:

[...] Pus manava-lhe

dos pés, gangrena corrosiva. Não

libávamos, ouvindo-lhe os queixumes,

as maldições ecoando em nossas tendas.

(SÓFOCLES, Filoctetes, 7-10, tradução de Trajano Vieira)

Quando sua ajuda torna-se imprescindível é apenas sua recusa que se pode esperar, mas, na peça de 409 a. C., o herói não tem outra saída senão render-se, abandonando sua vontade e seu desejo de justiça. Filoctetes é intransigente até a última cena, quando a aparição de Héracles o impede de prosseguir. Em outras tragédias de Sófocles, o herói, para manter sua honra, falha; em Filoctetes, ao contrário, o herói, sem que ele mesmo o queira, tem sucesso. A despeito de sua vontade e de sua fidelidade ao código guerreiro, Filoctetes abandonará sua solidão para reintegrar-se à guerra, onde poderá obter a glória e despedir-se de seu sofrimento, com a promessa da cura por Asclépio (BOYASK, 2007). ${ }^{7}$ Nessa peça de Sófocles existe, portanto, a necessidade da reintegração do herói como parte fundamental da democracia e do equilíbrio político dessa operação. Filoctetes é, na peça, o herói de outrora, que precisa ser levado de volta à pólis. Ele é o herói sem o qual o exército não pode ganhar a guerra, ou seja, é o herói que falta à pólis.

É verdade que o retorno do herói ferido para a guerra não é uma invenção do século $\mathrm{V}$. Filoctetes é mencionado em Homero, tanto no tocante à sua habilidade com o arco de Héracles (Il., II, 718; Od., VIII, 219-220), quanto no que diz respeito ao seu exílio em Lemnos e sua possível retomada da guerra (Il., 721-725), além de ter o seu retorno seguro à pátria mencionado pela Odisseia (III, 190). Dessas referências, ao menos a que ocorre no Canto II da Ilíada parece esconder uma versão muito mais desenvolvida e conhecida pelo público, podendo, por isso, ter sido apenas aludida no Catálogo dos navios (OLSON, 1991). É preciso notar, contudo, que não há, nem na Ilíada nem na Odisseia, evidência alguma de que o abandono de Filoctetes na ilha de Lemnos, em virtude de sua ferida, tenha sido orquestrado pela vontade de qualquer outro que não ele mesmo. Além disso, não existe a sugestão de que Odisseu tenha tomado a frente da empresa para o seu resgate. A

$7 \mathrm{Na}$ tragédia, Asclépio será o encarregado da cura de Filoctetes. Tornado deus em Atenas, Asclépio será homenageado com um templo ao lado do teatro de Dioniso. A construção acontece por volta de 420 , quando a cidade precisava da proteção e da cura, haja vista a praga que the matava um quarto da população (acredita-se que a praga tenha sido uma espécie de febre tifoide). 
Bibloteca de Apolodoro, posterior à tragédia de Sófocles, confirma a instrução de Agamêmnon a Odisseu para deixar Filoctetes em Lemnos munido de seu arco, mas os resumos de Proclo não o endossam. As Cíprias explicam apenas que Filoctetes fora deixado na ilha em função do mau cheiro de sua ferida, ocasionada pela picada de uma serpente.

Aportam em Tênedo. Filoctetes, picado por uma cobra-d'água enquanto ceavam, é abandonado em Lemnos por causa do maucheiro. (PROCLO, Cíprias, 144-5, tradução de Ícaro Gatti.)

Da Pequena Iliada, tem-se que Filoctetes de fato volta a Troia, embora o retorno dele seja assegurado não pelo filho de Aquiles, Neoptólemo, mas por Diomedes. Ademais, sabe-se daí que Neoptólemo (o qual, nessa narrativa, em nada se associa ao retorno de Filoctetes a Troia) recebe das mãos de Odisseu as armas de seu pai.

Depois disso Odisseu captura Heleno em uma emboscada; após um oráculo deste a respeito da tomada da cidadela, Diomedes traz Filoctetes de volta de Lemnos. Curado por Macáon, ele mata Alexandre em um duelo. Os troianos sepultam o cadáver depois de reavê-lo desfigurado por Menelau.

Depois disso Dêifobo toma Helena por esposa.

Após trazer Neoptólemo de Esquiro, Odisseu lhe entrega as armas do pai. Aquiles aparece para ele. (PROCLO, Pequena Ilíada, v. 211 -218)

Se, contudo, o retorno de Filoctetes à guerra, não é uma novidade para a Atenas Clássica, Sófocles inova em vários aspectos. Em Filoctetes, vê-se, além da transformação da personagem trágica, o modo pelo qual o desenvolvimento do enredo e seu resultado dependem absolutamente da interação de Filoctetes, e também de Odisseu, com Neoptólemo, sobretudo da influência que exercem sobre ele e um sobre o outro (KIRKWOOD, 1967). Na peça de 409 a. C., essa interação entre as personagens, a qual também pode ser pensada na perspectiva do embate, do ágōn, é levada ao limite. Sófocles põe em cena a divisão da pólis ou, mais precisamente, por meio da interação das personagens, póe em cena uma alusão às forças que se opõem no universo interno da pólis.

Na peça de Sófocles, existem duas forças básicas: de um lado, Odisseu; de outro, Filoctetes. Ambas tentam agir sobre uma nova força, que recebe, avalia, refuta e incorpora as influências: Neoptólemo. Seria a mistura dessas forças, ou uma tentativa de harmonizá-las, o que que se vê esboçar em Filoctetes? O 
conflito entre as personagens aponta de forma inegável para as inimizades que existem dentro de uma mesma comunidade e que a dividem, enfraquecendo-a. Tal como ocorre na história de Atenas, na tragédia de Sófocles, o elemento externo (a guerra de Troia) suplanta o conflito interno, forçando a unificar as partes, uma vez que, ao fim da peça, Filoctetes e Neoptólemo seguem para a guerra junto com Odisseu, até então o maior inimigo do herói abandonado. Neoptólemo, que busca se formar, estabelece como que uma ponte entre as duas forças já constituídas: entre a intransigência de Filoctetes, e a autoridade de Odisseu, que, ao contrário daquele, sabe abandonar suas convicçôes para dançar conforme a música. Em Filoctetes, Odisseu é, além disso, o homem das palavras, muito mais do que dos feitos. São as palavras que o guiam:

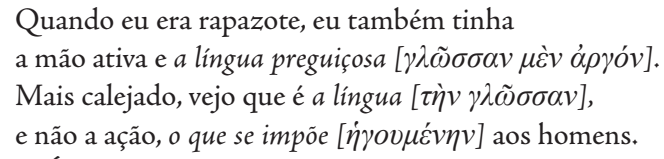

(SÓFOCLES, Filoctetes, 96-9)

Com sua habilidade, Odisseu, sabendo que deve enfrentar a hesitação de Neoptólemo ("Me aperta o peito ouvir tua fala; anula-me/ imaginar-me

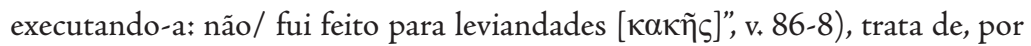
meio das palavras, tornar a trapaça mais palatável, a fim de que o filho de Aquiles consinta, conseguindo levá-la a cabo. Para o Laertíade, a vitória vale o sacrifício da virtude e é isso o que tenta ensinar ao jovem filho de Aquiles;

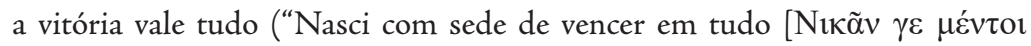

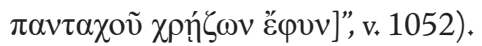

O philónikos, este que ama a vitória, é um tipo popular para o público ateniense do séc. $\mathrm{V}$ a. C., a julgar pelas ocorrências do termo nos autores coevos. Platão faz várias menções a ele. No Protágoras (336), é Alcebíades o philónikos

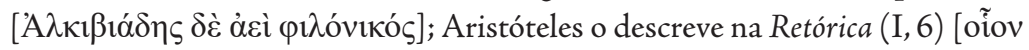

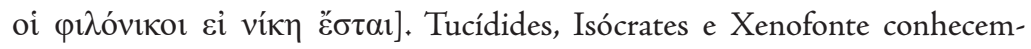
no também. Em Filoctetes, Odisseu "tem apenas uma causa; ele representa a vontade e a autoridade do exército" (KIRKWOOD, 1967, p. 145). ${ }^{8}$ Para ele, só a vitória pode dar a glória, e a justiça não é mais importante do que vencer, pois a justiça pode ser feita depois (ou pode, até mesmo, ser esquecida, como vai ser ao fim da peça):

Sei bem que foge ao teu feitio, menino, falar coisas assim, urdir ardis,

8 Texto original: has just a cause; be represents the will and the authority of the army. 
mas como conquistar vitória é doce,

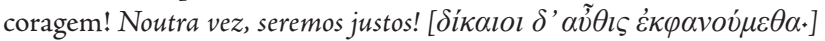
Cede à impostura por um dia único,

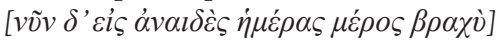

doa-te a mim, pois há tempo de sobra para escutares: "Eis um jovem probo!" (SÓFOCLES, Filoctetes, 79-85)

Odisseu tem ainda outro argumento para convencer Neoptólemo, para além do sabor doce da vitória. $\mathrm{O}$ jovem deve pôr em prática o valor da lealdade ao exército, deve estar sempre ao lado dos seus, executando as açóes que lhe forem designadas. Por isso, Odisseu faz Neoptólemo sentir o peso de sua responsabilidade: se ele falhar na execução do plano, ele arruinará todo o

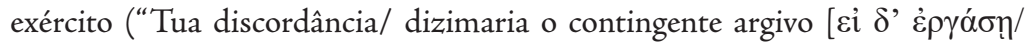

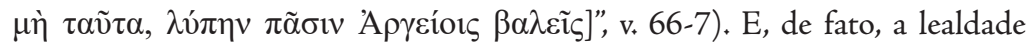
ao exército, é um elemento que pesa na consciência de Neoptólemo. Ele diz:

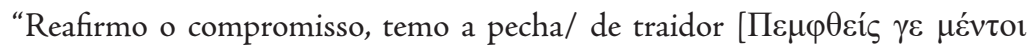

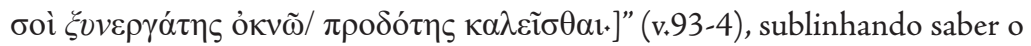
valor de seu compromisso para a comunidade (o que se confirma pelo prefixo

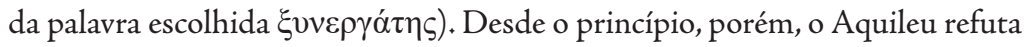
o dolo, desqualificando-o. Ele pergunta a Odisseu: "Não vês na farsa um golpe

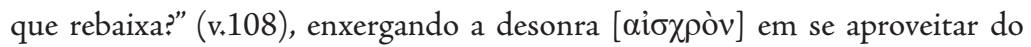
falso [ $\tau$ ò $\psi \varepsilon v \delta \tilde{\eta} \lambda \bar{\varepsilon} \gamma \varepsilon เ v]$. Neoptólemo não parece compartilhar os valores de Odisseu e envergonha-se do que faz ("Enganei um herói com truques baixos

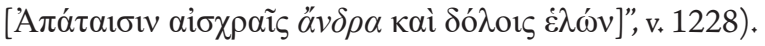

Neoptólemo, enfim, ainda que cumpra as ordens de Odisseu, não se identifica com ele. Ao contrário, ele se reconhece em Filoctetes, com quem compartilha a visão que tem do Laertíade. Ao perguntar sobre o pior dos homens que fora a Troia, Filoctetes faz Neoptólemo demonstrar a imagem ruim que tem de Odisseu. É verdade que Odisseu o desobriga de ter pejo para falar dele, pois, de fato, o que importa é o sucesso da ação ("Solta os cachorros

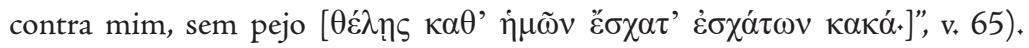
Neoptólemo advinha Odisseu na pérfida descrição de Filoctetes, quando este, referindo-se a Tersites, pergunta-lhe:

De fato, e é por isso que eu te indago que fim levou o tipo infame, exímio falastrão, se ainda vive ou faleceu. (SÓFOCLES, Filoctetes, 438-40) 
Ao qualificar Tersites, Filoctetes explora a mesma ambiguidade

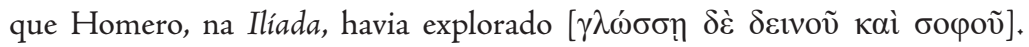
Detentores de uma língua afiada e perspicaz: é assim que tanto Tersites quanto Odisseu são igualmente qualificados no diálogo entre Neoptólemo e Filoctetes. Terríveis na fala, Tersites e Odisseu confundem-se no entrecho. De fato, para Neoptólemo, Odisseu representa, além da autoridade do exército, a malícia, a astúcia e a frouxidão moral. Odisseu já havia lhe sugerido que a moral seria uma espécie de máscara passível de ser vestida e tirada conforme a contingência ("Noutra vez, seremos justos!", v. 82). Não sendo possível vestila hoje, não haveria razão para sofrer. Odisseu, como Filoctetes, enxerga a

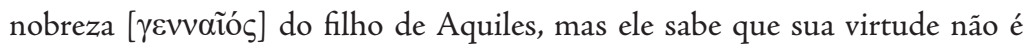
útil para a execução do plano do qual depende a vitória aqueia na guerra ("tua

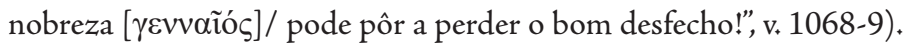

Gordon Kirkwood (1967) vê em Odisseu o símbolo do Estado. Odisseu, nesse sentido, não seria o vilão da história, nem ofereceria ao público a imagem oposta da virtude de Filoctetes, ao menos não o seu contrário numa perspectiva maniqueísta. Odisseu é a força da pólis, do princípio coletivo que deve prevalecer sobre a virtude individual. Segundo Bernard Knox (1964), todavia, Filoctetes e Odisseu funcionam, sim, como um par que revela ao público dois tipos ideais de homem e que demanda do próprio público uma sorte de escolha.

O Odisseu homérico é, sem sombra de dúvida, um homem de estratagemas e de palavras certas. Diferentemente de Aquiles, ele devota-se à vida, não à morte gloriosa, mas não hesita em arriscá-la para defender a honra: na ilha de Circe, por exemplo, quando Euríloco retorna como único sobrevivente, Odisseu não foge para salvar a própria pele (HOMERO, Odisseia, X, 273). O Odisseu sofocliano, em Ájax, também tem sua nobreza; uma nobreza distinta da nobreza de Ájax, posto que flexível e maleável às vicissitudes do mundo, mas ainda assim uma nobreza admirável, sendo apenas em função dela que a nobreza de Ájax permanece preservada como memória. O Odisseu sofocliano em Filoctetes, por sua vez, a quem só importa a vitória, mais se parece com o Odisseu euripidiano (KNOX, 1964).

Em Filoctetes de Eurípides, segundo Dion Crisóstomo (LII; LIX) ${ }^{9}$ Odisseu aparece na pele de um homem que, além de extremamente astuto, é urbano, pertence à pólis. $\mathrm{O}$ estrangeiro anônimo (Odisseu antes de se revelar) anuncia as grandes perdas na guerra a Filoctetes, em particular a morte de

9 Antes de Sófocles, tanto Ésquilo quanto Eurípides apresentaram, cada um, sua peça Filoctetes, das quais não nos restam mais do que alguns fragmentos e os comentários de Dion Crisóstomo. 
Agamêmnon e a desgraça do próprio Laertíade, como que buscando abrir caminho para a aderência do herói solitário à ideia de retornar à guerra (LII). O plano de Odisseu, na peça de Eurípides, conforme a apresentação de Dion Crisóstomo, assim, parece ser o de encorajar o retorno de Filoctetes, ganhando sua cumplicidade, a partir da informação de que os dois tinham exatamente os mesmos inimigos e de que tais inimigos estavam mortos. A partir do que se presume ser o prólogo da peça Filoctetes de Eurípides, sabe-se, conforme o que ele mesmo diz, que seus aliados consideram-no o melhor e o mais prudente

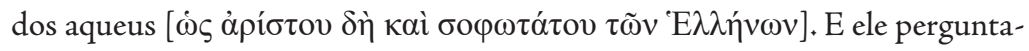
se que tipo de inteligência seria esta, a que faz quem trabalha mais do que os

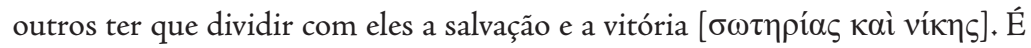
por amor à glória [ $\varphi \imath \lambda o \tau \uparrow \mu i ́ \alpha \varsigma]$ que esse Odisseu vai a Lemnos em busca de Filoctetes (DION CRISÓSTOMO, Discursos, LIX, 1).

O Laertíade de Eurípides, na peça em questão, é, para Dion Crisóstomo, um patife. O Odisseu de Sófocles, por sua vez, estaria a meio caminho, entre o herói nobre e simples de Ésquilo, que preserva as qualidades dos heróis de outros tempos, e o herói velhaco e sem escrúpulos de Eurípides (LII, 15). O Laertíade sofocliano teria dignidade, nobreza, e seria mais gentil e mais franco do que seu homólogo euripideano (LII, 16).

Diferentemente do que pensou Dion Crisóstomo, para Douglas Olson (1991), o Odisseu sofocliano seria aquele que cede à patifaria, revelando-se "um canalha completo, um depravado amoral do início ao fim" (OLSON, 1991, p. 282). ${ }^{10}$ Sófocles, e não Eurípides, teria transformado a história de Filoctetes na história da vileza moral de Odisseu, em que ele denunciaria, por meio da sua própria degradação, a degradação do homem político, afinal: "do começo ao fim, ele é sem dúvida o vilão, embora as opinióes possam variar sobre o grau de sua vilania; cada etapa na peça revela uma nova depravação em seu caráter" (STANFORD, 1954, p. 107). ${ }^{11}$ Nesse sentido, o Odisseu da peça Filoctetes de Sófocles, merece, segundo B. Knox (1964), os títulos que recebe injustamente em Ájax: filho de Sísifo, o enganador, o trapaceiro arquetípico. Também para Knox, ele não respeita, sequer minimamente, o código heroico; nenhum princípio guia sua conduta, a não ser o desejo de vitória, para o qual se volta com todos os seus esforços. Esse Odisseu sofocliano de Filoctetes é alguém que faz de tudo [ $\pi \alpha v o \tilde{\rho} \rho \gamma$ $\varsigma$ ] no sentido extremo: ele aceita fazer qualquer coisa para obter a vitória, não há valor que o impeça. Ele é aquele

10 Texto original: a complete scoundrel, amoral reprobate from start to finish.

11 Texto original: from beginning to end he is undoubtedly the villain, though opinions may vary about the degree of his villainy. Each development in the play reveals a fresh depravity in his character. 
que não se permite afetar pela fúria nem se deixa guiar pela força do corpo; é o homem cuja inteligência e astúcia controlam as ações. O Odisseu sofocliano de Filoctetes, é, assim, para boa parte da crítica, um tipo totalmente degenerado do homérico.

\author{
Muito teria a refutar, se o tempo \\ não premisse; por isso sintetizo: \\ eu danço - um camaleão - conforme a música.

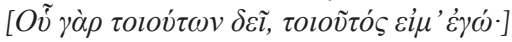 \\ Num teste por alguém correto e bom, \\ não há quem me anteceda em escrúpulo, \\ Nasci com sede de vencer em tudo

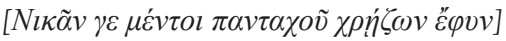 \\ (SÓFOCLES, Filoctetes, 1047-1052)
}

Longe de ser um tipo egoísta, Odisseu poderia, contudo, ser visto pela plateia que assistia à peça, em $409 \mathrm{a}$. C, como o democrata radical que pensa no grupo e que não hesita em fazer pagar o preço que precisa ser pago para o benefício do grupo (na história em questão, os guerreiros em Troia). Para Winnington-Ingram (1980), cuja leitura discorda da análise de B. Knox e D. Olson, Odisseu representa esse homem político, um tipo bastante reconhecível para o público. Ele está chefiando a missão em Lemnos como o enviado responsável pelo exército aqueu, que representa o exército, seus líderes e, portanto, a pólis. Odisseu se reconhece como uma peça que integra o exército

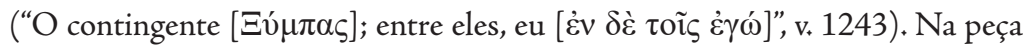
de Sófocles, ele também pode ser interpretado como um homem prudente, que não titubeia com relação aos propósitos de sua ação e que reconhece nela seu pertencimento à coletividade, sabendo que não cumprir a missão é se colocar contra o exército, contra a pólis. Diferentemente de Neoptólemo, a quem faz a pergunta, Odisseu não parece imaginar-se capaz de abandonar ou refutar um

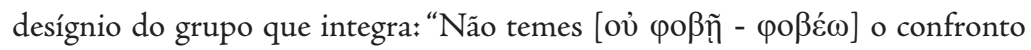
com o exército?" (v. 1250).

Seria de se pensar que, do ponto de vista democrático, de fato, esse Odisseu, tal como o descreve Winnington-Ingram, seria o ideal, o escolhido pelo público. Nele, versatilidade, adaptação (qualidade fundamental do ateniense, como elogia Péricles na "Oração Fúnebre" de Tucídides), habilidade diplomática, curiosidade intelectual combinam-se a fim de aproximá-lo da vitória. Do ponto de vista aristocrático, porém, os heróis da força são preferíveis ao herói das palavras, tanto mais se for este um Odisseu antes afeito ao dolo e às mentiras do que à ação impetuosa, como o Odisseu homérico. É a escolha que 
se vê em Píndaro: Ájax, e não Odisseu, é "o mais valente, depois de Aquiles" [ôv

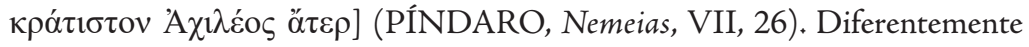
da escolha da pólis, do ponto de vista aristocrático, a preferência entre os dois heróis que se apresentam na peça de Sófocles (Odisseu e Filoctetes) recai, sem sombra de dúvida, sobre o herói da força: Filoctetes, aquele que confirma, indiretamente, o tipo heroico de Aquiles. Sófocles, portanto, participa do debate sobre o maior dos dois grandes heróis, do qual também participam poetas e sofistas, continuando a disputa que se vê iniciar desde a Ilíada e a Odisseia. A escolha do poeta, no entanto, não parece, de forma alguma, ingênua a ponto de identificar num dos heróis o caminho admirável e no outro o caminho perverso. Sua escolha sugere uma problematização das forças que então atuam sobre a pólis e que, embora reunidas após o golpe dos Quatrocentos, não consolidam, senão artificialmente, ${ }^{12}$ essa união.

\section{III - O EMBATE ENTRE DOIS Códigos E A ESCOLHA DE Neoptólemo}

Ao tornar o isolamento de Filoctetes maior e mais explícito do que o isolamento de qualquer outro de seus outros heróis, bem como ao torná-lo maior e mais explícito do que o isolamento do Filoctetes de Eurípides e de Ésquilo, Sófocles aprofunda tanto a dificuldade quanto a necessidade da sua reintegração. A abertura da peça já é uma evidência disso:

Eis que se descortina o cabo que ôndulas

lêmnias circum-envolvem. Rastros de homem não há, tampouco traços de morada.

(SÓFOCLES, Filoctetes, 1-3)

Filoctetes vive durante dez anos na ilha deserta de Lemnos. A possibilidade de seu retorno à guerra contrasta com esse ambiente em que poucos traços de civilização se apresentam: uma cumbuca, alguns panos fétidos, certos sinais de fogo. Sófocles parece querer enfatizar com a ausência de qualquer forma de coletividade, o isolamento agudo do herói:

\footnotetext{
12 Adiante, o estudo busca discutir a ideia de que a vitória democrática sobre os Quatrocentos busca, a partir de 411 a. C., afirmar-se filiando-se ao passado democrático da pólis e apagando as marcas do golpe dos Quatrocentos. Não obstante, a tragédia é uma das frentes que nos permite apreender não apenas a vontade política do momento mas a fragilidade dessas medidas democráticas.
} 


\section{ODISSEU}

Há no interior sinais de que é um lar?

NEOPTÓLEMO

Será um leito o tufo de folhagem?

ODISSEU

Mas isso é tudo sob o teto? E o resto?

NEOPTÓLEMO

Há uma copa de pau, que um pobre artífice

fabricou, mais uns trochos para o fogo.

ODISSEU

Pareces indicar-me seu tesouro.

NEOPTÓLEMO

Oh, céus! Que nojo! Uns panos rotos cheios

de purulento pus secam ali!

(SÓFOCLES, Filoctetes, 32 - 39)

A solidão do herói, não somente no plano imagético, mas no plano vocabular, é enfatizada pela frequência com que aparece no texto a palavra

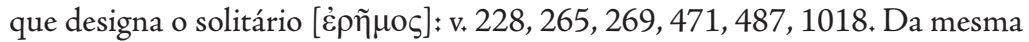
maneira que o contraste lexical marca a passagem de Neoptólemo da infância para a vida de adulto e, portanto, para a guerra, $\dot{\varepsilon} \rho \tilde{\eta} \mu$ $\zeta$ confronta-se com a $\pi$ ó $\lambda$ s $(v .1018,1213,1424),{ }^{13}$ num jogo que também indica a mudança da condição de uma personagem: Filoctetes passa de seu isolamento selvagem à reintegração social. Apesar de não dar mostras de hesitar com relação ao código heroico que segue, e de abrir mão dele apenas a partir da ordem divina, para Charles Segal (1981), antes de seguir a ordem do deus, Filoctetes precisa recobrar a confiança no homem. Ele quer, em outras palavras, poder sentirse capaz de abandonar sua solidão antes de perceber que terá que se agregar, novamente, aos homens. E a comunicação entre os dois lados está, desde seu abandono, ameaçada, tornando-se possível apenas por meio de um jovem que se vê dividido: estando prestes a se tornar um guerreiro, ele deve fazer suas escolhas entre os dois tipos de heroísmo cujos paradigmas na peça são Filoctetes e Odisseu. Ele escolhe Filoctetes.

Neoptólemo percebe que seus valores e os valores de seu pai se reconhecem em Filoctetes. Com Neoptólemo, Filoctetes não apenas fará uma nova amizade, rompendo com seu isolamento, recobrando a confiança no homem, feito essencial para a transformação pela qual precisa passar (SEGAL, 1981), como vai, com isso, criar o laço que a coletividade não pode, aos olhos do

$13 \mathrm{Na}$ fala de Filoctetes, a palavra também aparece, mas como que para confirmar seu isolamento: "apátrida" (v. 1018) e, depois, quando de sua reflexão sobre o suicídio como saída: "Ó pólis, ó pólispátria" (v. 1213). Por fim, a palavra é dita por Héracles em sua aparição ao fim da peça (v. 1423). 
herói, deixar de cultivar, a philía. Ao contrário de Odisseu, a fala de Filoctetes será marcada por palavras constituídas pelo radical phil-(BLUNDELL, 1989):

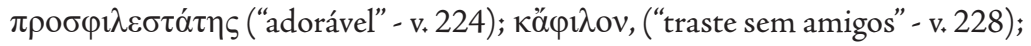

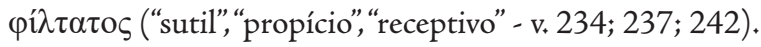

Filoctetes e Neoptólemo, phíloi, vão, porém, precisar ceder um pouco. O deus do escudo hoplítico não tem outra função na peça senão impedir o conflito interno, a divisão. Ele, como a pólis em 411 a. C., por meio da intervenção dos hoplitas do Pireu, próximos a Atenas, e dos hoplitas e marinheiros de Samos, vai buscar instituir a unidade. $O$ poeta põe em cena, assim, o desafio de recriar uma sociedade saudável capaz de curar a adoecida, seja ela representada por um Odisseu que não respeita a philía, seja por um Filoctetes abandonado que só quer punir seus inimigos, conforme o código épico.

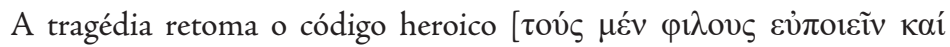
$\dot{\varepsilon} \kappa \theta \rho o u ́ \varsigma \kappa \alpha \kappa \hat{\zeta}$ ], como se quisesse colocá-lo à prova: examina sua história para enxergar a que ponto ele pode chegar. Enraizado na épica, esse código ajuda a entender o que levam os heróis homéricos a regozijarem-se sobre suas vítimas. A morte em batalha é o pagamento pelas mortes provocadas. Nesse sentido, o que sofre não merece piedade, posto que ele tem no sofrimento o preço justo a pagar. Tal como acontece com os heróis épicos, apenas um princípio guia a conduta do Filoctetes sofocliano, e é por sua fidelidade a ele que o herói o repete: "aos amigos fazer o bem, aos inimigos o mal".

$\mathrm{Na}$ genealogia desse código, um fragmento de Arquíloco sugere sua

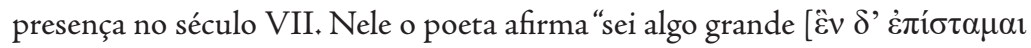

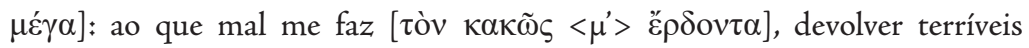

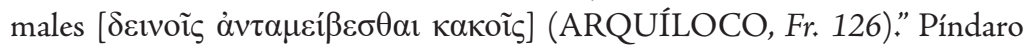
confirma a tradição (PÍNDARO, Nemeias, VIII, 35-45). E, se o código tem, senão seu início na épica, o que seria pouco provável, ao menos tem a partir dela seus registros, os quais, tais como em Arquíloco e em Píndaro, apontam para um afluxo que desagua no século $\mathrm{V}$, de modo que mesmo na pólis democrática tal pensamento orientará, embora não sem conflito, a conduta cidadã (BLUNDELL, 1989). Conforme o código, o que quer que aconteça com o homem odiado gera no homem que odeia o sentimento contrário: o sucesso do inimigo é doloroso para ele, bem como a queda do inimigo lhe gera prazer.

No século $\mathrm{V}$, o pensamento parece, aliás, conservar um teor banal. $\mathrm{O}$ discurso de Gilipo às tropas espartanas e siracusanas apela, de fato, ao senso comum: a vingança contra os inimigos, como diz o provérbio [ $\tau o ̀ ~ \lambda \varepsilon \gamma o ́ \mu \varepsilon v o ́ v$ ], é o mais doce dos prazeres (TUCÍDIDES, História da Guerra do 
Peloponeso, VII, 68). Tucídides, ademais, parece aceitá-lo. Para citar apenas outra passagem, contra a morte dos prisioneiros espartanos pelos atenienses, que jogaram em seguida os cadáveres em desfiladeiros, o historiador justifica o ato pelo princípio: é justo prejudicar o inimigo, utilizando o método mesmo dele (II, 67). Heródoto, antes dele, também testemunha o código nas histórias que conhece. Para citar apenas uma passagem, mas bastante significativa, o historiador conta como um inimigo será prejudicado por aquele que outrora prejudicara. Hermôtimos, para executar a vingança contra aquele que the tornara eunuco, sendo bárbaro, assevera a regra:

Ora, enquanto o Rei estava em Sárdis preparando-se para levar as
forças persas contra Atenas, Hermôtimos foi mandado em uma
missão a certo lugar da Mísia, habitado por quianos e chamado
Atarneus, e lá encontrou Paniônios. [...] Depois de apostrofá-lo,
Hermôtimos mandou avançarem os filhos de Paniônios e obrigou-o
a castrar os próprios filhos, que eram quatro; cedendo à compulsão,
Paniônios obedeceu, e depois de castrados seus filhos foram também
constrangidos a castrá-lo. Assim Paniônios foi colhido pelo castigo
e Hermôtimos vingou-se. (HERÓDOTO, História, VIII, 106,
tradução de Mário da Gama Kury)

Xenofonte também sabe dar sua contribuição. Num diálogo entre Sócrates e Critóbulo, o primeiro fala sobre a amizade e a inimizade, seguindo a mesma regra. Sócrates diz a Critóbulo serem os homens naturalmente

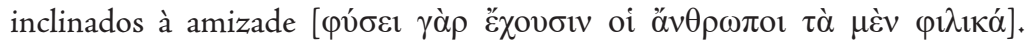
Apiedam-se, colaboram entre si, ficam gratos uns para com os outros. Entretanto, eles são também dados à inimizade [ $\tau \grave{\alpha} \quad \delta \dot{\varepsilon} \pi 0 \lambda \varepsilon \mu 1 \kappa \alpha ́$ ]: ao considerarem as mesmas coisas belas e agradáveis, competem entre si, e, ao divergirem de opinião, entram em conflito. Sua inimizade nasce também da

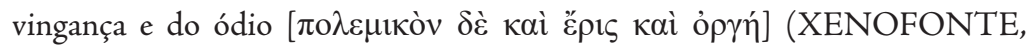
Memorabilia, II, 6, 21).

$\mathrm{Na}$ tragédia, em geral, não apenas em Sófocles, o código é levado à cena. Em Eurípides, para citar apenas passagens rápidas:

Porque que é normal homem nobre fazer justiça e fazer sempre o mal pros que são maus, de qualquer jeito!

(EURÍPIDES, Hécuba, 844-5, tradução de Andreza Moreira)

Que tudo dê certo! Por que isso é igual para todos, para cada um e para cidade: que quem é ruim sofra algo ruim; e quem é bom, seja feliz! (EURÍPIDES, Hécuba, 905) 
O século $\mathrm{V}$, nesse sentido, mostra aceitar o código, portador de uma concepção própria de justiça, mas outros registros coevos não deixam, por outro lado, de revelar possíveis exceções e até mesmo de questioná-lo. O código heroico anuncia, por sua natureza mesma, atritos com a pólis. A multiplicação de laços, gerada pelas amizades e pelas inimizades, leva à proliferação de lealdades, e esse quadro de lealdades guarda grandes chances de entrar em conflito com determinações que não olham para as relações pessoais, mas para a cidade como um todo, como um corpo só.

É este o impasse que Atenas enfrenta - ao menos parece ser essa a opinião de Sófocles, quando responde por que votara no estabelecimento do regime oligárquico de 411 a. C. ${ }^{14}$

Sófocles, tendo-lhe perguntado Pisandro se ele não havia decidido, com os demais membros do Conselho, por estabelecer os Quatrocentos no poder, respondeu afirmativamente. Então disse Pisandro: "Como? Não te parece ter sido essa uma decisão terrível?" Sófocles confirmou. Pisandro: "Ousaste cometer essa terrível ação?" "Sim, respondeu o poeta, pois não havia outra solução melhor". (ARISTÓTELES, Retórica, 1419a)

Ao justificar o voto por falta de melhor opção, Sófocles não nega seu voto nos Quatrocentos, mas ao mesmo tempo refuta tanto os excessos da democracia de 411 a. C. quanto os excessos cometidos pelo regime que seria instaurado então, o qual se impôs pela força, reduzindo ao silêncio, enquanto lhe foi possível, os principais adversários com a prisão ou com a morte (TUCÍDIDES, História da Guerra do Peloponeso, VIII, 70, 2). Em 409

a. C., o poeta parece fazer um balanço do que restara dos anos de guerra e de turbulência política. O julgamento de Neoptólemo, segundo o qual "na guerra os bons perecem, restam os maus" ( $v$. 436-7 e que se confirma em v.

14 Apesar de alguma resistência da crítica, não parece ser plausível que Aristóteles tenha se referido a outro Sófocles que não o poeta. Segundo Tucídides, em 413, os atenienses decidem, num último fôlego, não renunciar, mas equipar uma frota a fim de consolidar sua aliança sobretudo com a Eubeia, reduzindo algumas despesas públicas e, por fim, elegendo uma comissão de anciãos, encarregados de fazerem proposições sobre a situação vivida, que não tinha duração determinada (TUCÍDIDES, 8, 1, 3-4). Sófocles, já em idade adiantada, exerce então sua última função política. Essa última responsabilidade que os atenienses lhe confiaram foi exatamente num momento de crise da democracia, após o desastre da expedição da Sicília em 413. Sófocles e outros nove próbouloi são os encarregados de protegerem Atenas, discutindo sobre possíveis soluções para a crise. O grupo é responsável, porém, por votar a Revolução Oligárquica dos Quatrocentos em 411. E, com a implantação de fato do novo regime, os dez comissários veem seu poder reduzir-se, pois vinte outros próbouloi passam a integrar a comissão, tornando os dez anteriores minoria em trinta. O novo regime dissolve a Assembleia e várias outras instituições democráticas. Mas o golpe dura pouco. 
412, 417, 428, 446-450) ganha novos contornos ao fim da peça. O filho de Aquiles aprende que a melhor saída pode ser mesmo a de reintegrar o velho herói, ermo por tantos anos na ilha de Lemnos. ${ }^{15}$ Filoctetes, o herói de outro tempo, será resgatado na ilha onde havia sido deixado, pois, mesmo sendo o herói de outro tempo, ele deve ter seu espaço assegurado na pólis. Sófocles desconfia da unidade, mas, ainda assim, depois de 411 a. C., prefere a unidade à escolha de um dos lados. Por meio de Neoptólemo, o poeta reitera a atitude democrática do diálogo, do conviver, do viver junto, em contraponto à morte de um dos lados, como acontece em Ájax. O Coro de 409 a. C. de fato conclama

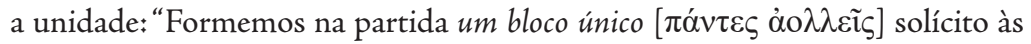
Nereidas oceânicas: zelai pelo retorno sem transtorno!" (Filoctetes, 1469-71).

Há, no entanto, um intervalo entre a reintegração do herói à pólis e sua reintegração efetiva, nas palavras de Julia Shear (2011), que Sófocles captura bem.

Não é distinto o que deves sofrer: do múltiplo sofrer aflora a glória. Tomando a direção da pólis troica, darás um fim à agrura de tua úlcera, te tornas o ás do exército por mérito.

A Páris, causador de males múltiplos, anulas, alanceando-o com meus dardos [ $\tau$ ó

Devassas Îlion e o butim que o exército te reserva, o melhor, envias ao lar, ao pai Poianto, ao Eta, altiplano.

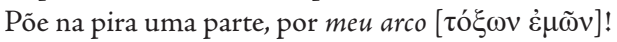

Eis o que te aconselho, Aquileu: a tomada de Troia, belo campo, dependerá da mútua confiança [oü $\theta$ ' oṽ qual dupla de leões que caçam juntos

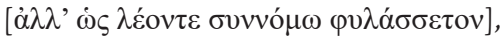

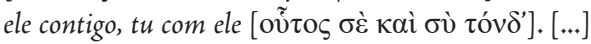
(SÓFOCLES, Filoctetes, 1421-36)

$15 \mathrm{O}$ poeta, aliás, era, sem dúvida, tal como a plateia, consciente do laço que ligava Atenas a Lemnos. Tucídides registra como os líderes atenienses, em guerra para instaurar a democracia na ilha, tomaram como reféns dos sâmios cinquenta meninos e cinquenta homens, os quais, levados a Lemnos, terão que esperar por lá até serem resgatados por conterrâneos (TUCÍDIDES, I, 115). Os atenienses retiraram-se de Samos após a tomada do poder. Alguns sâmios, porém, não se conformam com a situação e fogem para o continente; depois, juntam forças com homens mais influentes que haviam ficado na ilha e reúnem tropas mercenárias antes de voltarem a Samos. Lá, instigam os habitantes contra os democratas, buscam os reféns deixados em Lemnos e se rebelam contra Atenas. 
Não há dúvida de que Filoctetes se curva à vontade do deus: ele vai retornar à guerra e vai se unir à pólis, mas sua reintegração não inclui o cumprimento da justiça que o herói reivindica, qual seja, a punição de seus inimigos (a mesma que já reivindicara Ájax), estando Odisseu entre eles.

A peça torna, assim, as dificuldades para a criação de alguma unidade ainda mais evidentes do que elas são na realidade de uma multidão que repete lado a lado o voto de proteger o companheiro na guerra como orienta a moral hoplítica ("Eu não abandonarei meu vizinho quando eu estiver a seu lado na batalha") ou de matar o inimigo da democracia como diz o Juramento de Demofanto ("Matarei, por palavra, por feito, por voto, por minha própria mão, se eu puder, qualquer um que derrube a democracia em Atenas"). Ao poeta interessou pôr em cena não o retorno do velho herói, determinante para a vitória aqueia. Interessou-lhe explorar a limitação de seu retorno, posto que inevitável. Sófocles evidencia, com Filoctetes, justamente as dificuldades que a unidade da pólis não deixa transparecer em seus novos e velhos ritos democráticos. Afinal, nas Grandes Dionísias de 409 a. C., ao lado da vitória de Sófocles com sua peça Filoctetes, entra para a história também Trasíbulo de Cálidon. Trasíbulo ganha a coroa de ouro por ter assassinado o oligarca Frínicoः um tirano em potencial, para quem não havia lugar no "bloco único" ${ }^{16}$

THE DIFFICULTIES OF ATHENS IN RETURNING TO DEMOCRACY AFTER THE ATHENIAN COUP OF 411 BC OR WHEN A HERO OF THE PAST NEEDS TO REINTEGRATE INTO POLIS IN PHILOCTETES BY SOPHOCLES

\begin{abstract}
This paper analyzes Philoctetes by Sophocles, performed at the Festival of Dionysus, where it won first prize in 409 BC, year in which the first festival takes place after the resumption of the power by people after the Athenian Coup of the Four Hundred. In that play, Philoctetes remains the lonely hero. He is, however, at the same time, the hero who must become assimilated again into the polis. Beside him, Neoptolemus, a character who considerably modifies the myth, becomes as history unfolds the new Achaean warrior who learns to recognize the value of philia and the value of unity, but does not do so without inviting the Athenian spectators to reflect on the civic oaths and on the unity that these rites sought to fulfill.
\end{abstract}

Key-words: Philoctetes; Hero; Polis; Democracy 


\section{Bibliografia}

Documentação textual

ANDOCIDES. Minor Attic Orators in two volumes: 1, Antiphon, Andocides, with an English translation by K. J. Maidment. Cambridge; London: Harvard University Press; William Heinemann Ltd., 1968.

ARISTOTE. Rhétorique. Livre III. Texte établi et traduit par DUFOUR, M. et WARTELLE, A. Paris: Les Belles Lettres, 1973.

ARISTOTELIS ARS RHETORICA, Ed. Ross, W.D. Oxford: Clarendon Press, 1959, Repr. 1964.

DIO CHRYSOSTOM. Discourses - IV (in five volumes). Transl. H. Lamar Crosby. Cambridge: Harvard University Press, 1962.

Dionis Prusaensis quem vocant Chrysostomum quae exstant omnia, vols. 1-2, 2nd edn., Ed. von Arnim, J. Berlin: Weidmann, 1:1893; 2:1896, Repr. 1962.

EURÍPIDES. Hécuba, De Eurípides: Uma Perspectiva De Tradução. 2015. Dissertação (Mestrado em Letras) Andreza Sara Caetano de Avelar de Moreira. Universidade Federal de Minas Gerais. Programa de Programa de Pós Graduação em Estudos Clássicos da Faculdade de Letras, Belo Horizonte. 2015.

HÉRODOTE. Históire d'Hérodote. Trad. du grec par Larcher; avec des notes de Bochard, Wesseling, Scaliger. Paris: Charpentier, 1850. (Pour le texte grec: ed. A. D. Godley. Cambridge 1920).

HÉRODOTE. L’Enquête. Édition d'Andrée Barguet. Paris: Gallimard, 1990.

HERÓDOTO. História. Tradução do grego, Introdução e Notas de Mário da Gama Kury. Editora Universidade de Brasília, 1985.

Homeri Ilias, vols. 2-3, Ed. Allen, T.W. Oxford: Clarendon Press, 1931.

Homeri Odyssea, Ed. Peter von der Mühll, P. Basel: Helbing \& Lichtenhahn, 1962. HOMERO. Ilíada. Tradução de Frederico Lourenço. São Paulo: Penguin Classics; Companhia das Letras, 2013.

HOMERO. Odisseia. Tradução de Frederico Lourenço. São Paulo: Penguin Classics; Companhia das Letras, 2011.

IAMBI ET ELEGI GRAECI. Vol. 1, Ed. West, M.L. Oxford: Clarendon Press, 1971.

PINDARE, Tome III. Néméennes. Texte établi et traduit par Aimé Puech. Paris, Les Belles Lettres, 1967.

PINDARI CARMINA CUM FRAGMENTIS, pt. 1, 5 th edn., Ed. Maehler, H. (post B. Snell) Leipzig: Teubner, 1971.

PLATONIS OPERA, vol. 3. Ed. Burnet, J. Oxford: Clarendon Press, 1903, Repr. 1968.

PROCLO. A Crestomatia de Proclo: Tradução integral, notas e estudo da composição do códice 239 da Biblioteca de Fócio. 2012. 155f. Dissertação (Mestrado em Letras), Programa de Pós-Graduação em Letras Clássicas da Faculdade de Filosofia, Letras e Ciências Humanas da Universidade de São Paulo, São Paulo. 2012.

PROCLUS. Greek epic fragments: from the seventh to the fifth centuries BC. Martin L. West (edition and translation). Cambridge, Mass.; London: Harvard University Press, 2003. E também: PROCLO. Crestomatia.

PROCLUS. Chrestomathia. Recherches sur la Chrestomathie de Proclus, vol. 4, Ed. Severyns, A. Paris: Les Belles Lettres, 1963. 
THUCYDIDE. La Guerre du Péloponnèse. Texte présenté, traduit et annoté pas Denis Roussel. Préface de Vidal-Naquet. Paris: Gallimard, 2000.

THUCYDIDIS HISTORIAE, 2 vols., Ed. H. S. Jones, J. E. Powell. Oxford: Clarendon Press, 1942; 1967.

TUCÍDIDES. História da Guerra do Peloponeso. Prefácio de Helio Jaguaribe; Trad. do grego de Mário da Gama Kury. 4a. edição. Brasília; São Paulo: Editora Universidade de Brasília, Instituto de Pesquisa de Relações Internacionais; Imprensa Oficial do Estado de São Paulo, 2001.

XENOPHONTIS OPERA OMNIA, v. 2, 2nd edn,", Ed. Marchant, E.C. Oxford: Clarendon Press, 1921, Repr. 1971.

XÉNOPHON. Mémorables. Texte établi par Michele Bandini. Traduit et annoté par Louis-André Dorion. Paris: Les Belles Lettres, 2011.

Referências bibliográficas

CAMPBELL, Lewis. Sophocles, Plays and Fragments, II. Oxford, 1881.

JOUANNA, Jacques. Sophocle. Paris: Librarie Arthème Fayard, 2007.

KIRKWOOD, Gordon MacDonald. Chapter III - Character Portrayal. In: 1967. . A study of sophoclean drama. Cornell University Press. Ithaca, New York,

KNOX, Bernard. Chapter 5: Philoctetes. In: The Heroic Temper: Studies in Sophoclean Tragedy. Berkeley; Los Angeles: University of California Press, 1964.

MITCHELL-BOYASK, Robin. The Athenian Aesklepion and the end of Philoctetes. In: Transactions of the American Philological Association, v. 137, n. 1, 2007, p. 85-114.

OLSON, Douglas. Politics and the Lost Euripidean Philoctetes. In: Hesperia: The Journal of the American School of Classical Studies at Athens, v. 60, n. 2, p. 269-283.

SEGAL, Charles. Chapter 10. Philoctetes: Society, Language, Friendship. Tragedy and Civilization: an Interpretation of Sophocles. Harvard University Press, 1981.

SHEAR, Julia L. Polis and Revolution: responding to Oligarchy in Classical Athens. Cambridge University Press, 2011.

STANFORD, William Bedell. The Ulysses Theme. Oxford: Basil Blackwell, 1954.

VIDAL-NAQUET, Pierre. Ajax ou la mort du héros. In: VERNANT, JeanPierre; VIDAL-NAQUET, Pierre. La Grèce ancienne. III. Rites de passsage et transgressions. Paris: Éditions Points, 2009.

WINNINGTON-INGRAM, Reginald P. Chapter 12. "Philoctetes". In:

P. Sophocles: an interpretation. Cambridge: Cambridge University Press, 1980. 